\title{
$\mathrm{Zn}-\mathrm{Cu}-\mathrm{Mg} 3$ 元系合金平衡状態図の亜鉛隅に関する研究
}

\section{山田正夫讼木賢 司**}

Masao Yamada and Kenji Matuki : A Study of the $\mathrm{Zn}$-rich Corner of the $\mathrm{Zn}-\mathrm{Cu}-$ $\mathrm{Mg}$ Phase Diagram. The phase diagram of the $\mathrm{Zn}-\mathrm{Cu}-\mathrm{Mg}$ ternary system in the range of less than $\mathrm{Cu} 30 \mathrm{wt} \%$ and $\mathrm{Mg} 16 \mathrm{wt} \%$ was investigated by means of differential thermal analyses and microscopic examinations. The phase determination was also performed with the aid of EMPA analysis. The results were summarized as follows: (1) A new diagram was obtained in which the $\mathrm{Zn}$-rich corner with compositions up to $\mathrm{Cu} 5 \mathrm{wt} \%$ and $\mathrm{Mg} 5 \mathrm{wt} \%$ was clarified in contrast to the previous diagrams reported by two othre authors. (2) The liquidus surface of the $\mathrm{MgZn}_{2}$ phase was found to exist, which resulted in the occurrence of a ternary peritecto-eutectic reaction. (3) In the range studied, five peritecto-eutectic reactions and one ternary eutectoid reaction were found to take place as follows :
(a) $L+\varepsilon \rightleftharpoons \eta+\mathrm{Mg}_{2} \mathrm{Zn}_{11}$
$367^{\circ} \mathrm{C}$
(b) $L+D \rightleftharpoons \varepsilon+\mathrm{Mg}_{2} \mathrm{Zn}_{11}$
$378^{\circ} \mathrm{C}$
(c) $L+\mathrm{MgZn}_{2} \rightleftharpoons \mathrm{Mg}_{2} \mathrm{Zn}_{11}+D \quad 380^{\circ} \mathrm{C}$
(d) $L+\delta \rightleftharpoons \varepsilon+D$
$515^{\circ} \mathrm{C}$
(e) $L+\gamma \rightleftharpoons \delta+D$
$557^{\circ} \mathrm{C}$
(f) $\delta \rightleftharpoons \varepsilon+\gamma+D$ about $400^{\circ} \mathrm{C}$.
(Received November 22, 1971)

\section{I. 緒 言}

著者ら ${ }^{(1)}$ は既に展伸用 $\mathrm{Zn}-2.0 \% \dagger \mathrm{Cu}$ 合金に及ぼす微量 元素添加の影響について研究し，その結果微量の $\mathrm{Mg}$ 元素 を添加した場合，その機械的強度をいちじるしく高めると ともに，時効硬化現象などが現われることを知った．この ような $\mathrm{Mg}$ 元素添加の影響を理解するためには，まず Zn$\mathrm{Cu}-\mathrm{Mg} 3$ 元系状態図の $\mathrm{Zn}$ 隅を明らかにする必要がある。

しかし本 3 元系状態図に関する従来の研究は, Köster ${ }^{(2)}$ および渡辺 ${ }^{(3)}$ のも以外には全くみられないようである. しかもこの両者の状態図は, その大筋については大体一致 しているにかかわらず, $\mathrm{Cu}$ および $\mathrm{Mg}$ 成分の少ない $\mathrm{Zn}$ 隅 の領域に打ける相平衡の関係は全く異なっている. そこで これらの点を明らかにするとともに，各相の平衡関係を知 るため， Cu 30\% 以下， Mg 16\% 以下の成分範囲にわたる $\mathrm{Zn}$ 隅の全領域について研究した。

\section{II. 本 3 元系平衡状態図に関連する 従来の研究}

\section{1. 本 3 元系状態図を構成する各 2 元系状態図}

本 3 元系状態図の基礎となる $\mathrm{Zn}-\mathrm{Cu} 2$ 元系状態図は Hansen ${ }^{(4)}$ とよって総合されたものを採用した。C Cu 30\%ま での範囲内には $\mathrm{Zn}$ 側より $\eta, \varepsilon, \delta$ および $\gamma$ の各固溶体が

** 富山大学工学部生産機械工学科 (Department of Production Machining, Faculty of Engineering, Toyama University, Takaoka)

* 1968 年 9 月本会仙台大会に発表

（1）山田, 時沢, 松木: 富山大学工学部紀要, 22 (1971), 73,85 .
存在する. 次に本 3 元系状態図のも5一方の基礎をなす

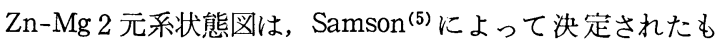
のを採用した． $\mathrm{Mg} 16 \%$ までの範囲内には $\mathrm{Zn}$ 側のク固溶 体のほか, $\mathrm{Mg}_{2} \mathrm{Zn}_{11}$ および $\mathrm{MgZn}_{2}$ の金属間化合物を主体 とした中間固溶体が存在する．ささらに本 3 元系状態図で

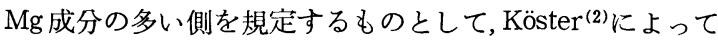
確かめられた $\mathrm{MgCu}_{2}-\mathrm{MgZn}_{2}$ 準 2 元系状態図を採用した。 $\mathrm{MgCu}_{2}$ に $\mathrm{n}$ が広い範囲にわたって固溶し(著者らは以後 $\mathrm{D}$ 固溶体と呼ぶ)，固溶 $\mathrm{Zn}$ 量の增加飞従って ( $\mathrm{Mg}$ は $16 \%$ 一定) $\mathrm{Cu}$ はしだいに Zn で置換され，Zn がちょうど51\% となると $\mathrm{CuMgZn}$ の組成をもつ 3 元金属間化合物すなわ ち著者らのいわゆる D化合物となる．もちろんこの化合物 の結晶格子は $\mathrm{MgCu}_{2}$ と同じ複雑立方(C 15) 型である。なお この準 2 元系状態図には 1 個の包晶反応が存在している. 本 3 元系状態図で $\mathrm{Cu}$ 成分の多い側を規定するもら一方の

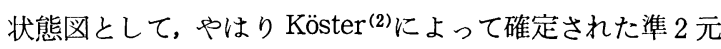
系状態図を採用した。 これは $\mathrm{Zn}-\mathrm{Cu} 2$ 元系状態図における $\gamma$ 固溶体と成分 $\mathrm{Mg}$ との間に成立する準 2 元系である。 こ の状態図は $16 \% \mathrm{Mg}$ の D 化合物のところで分離すること ができる.

著者らの研究せんとする $\mathrm{Zn}-\mathrm{Cu}-\mathrm{Mg} 3$ 元系平衝状態図 の $\mathrm{Zn}$ 隅は，以上に述べた 4 個の 2 元系で区切られた $\mathrm{Zn}$ 成分の多い側の 3 元系状態図である.

(2) W.Köster : Z.Metallk., 39 (1948), 352.

（3）渡辺：金属学会誌, $24(1960), 672$.

(4) M.Hansen : Const. of Binary Alloys, (1958), 650.

(5) S.Samson : Acta Chem. Scand., 3 (1949) , 835.

†すべて重量\%で表わす。 


\section{Zn-Cu-Mg 3 元系状態図の $\mathrm{Zn}$ 隅}

すでに述べたように，本 3 元系状態図の Zn 隅に関する 従来の研究結果は前述の二つの発表以外にはみられない. Koster の状態図では $520^{\circ}, 375^{\circ}$ および $370^{\circ} \mathrm{C}$ の各温度に 和ける 3 個の包共晶反応の存在が認められる，渡辺の状態 図では $540^{\circ}, 525^{\circ}, 390^{\circ}$ および $380^{\circ} \mathrm{C}$ の各温度における 4 個の包共晶反応の存在が認められ, さらに約 $400^{\circ} \mathrm{C} に お 。$ ける 3 元共析反応の存在が述べられている.このように両 者の状態図に拈ける不変系反応の不一致は, 主として Koster が Zn-Cu 2 元系に存在する $\delta$ 固溶体を無視して 3 元系状態図を作成したためである，このことと，各不変系 反応温度の不一致を除外して考察すると，大体において 両者の状態図の各反応面は対応していることがうかがわれ る.しかしながら基本的に大きな相違が存在する.

それは最低温度に打ける包共晶反応に対する考え方であ って, Koster は最低温度の包共晶点を $\mathrm{Zn}-\mathrm{Cu} 2$ 元系の包 晶点より降下しているとしているのに対して, 渡辺は Zn$\operatorname{Mg} 2$ 元系の包晶点より降下しているとしていることであ る. な打両状態図とも D以外には 3 元金属間化合物の存在 を認めていない.

\section{III. 実 験 方 法}

使用した地金は $99.998 \%$ 高純度亜鉛, 電気銅および $99.9 \%$ 電解マグネシウムである.試料は Zn-15 および $20 \%$ $\mathrm{Cu}$ 母合金によって $\mathrm{Cu}$ 成分を，また $\mathrm{Zn}-40$ および $50 \% \mathrm{Mg}$ 母合金によって $\mathrm{Mg}$ 成分を，それぞれ添加した各種組成の 合金 52 個である。すべてアルゴンガス雾囲気下で溶製し
た. 化学分析の結果を Table 1 に示したが目標值にほぼ 一致した。

実験は主として示差熱分析と光学顕微鏡による組織観察 によった. 示差熱分析は $2^{\circ} \mathrm{C} / \mathrm{min}$ の冷却速度で冷却し， 高感度記録計によって冷却曲線を自記せしめた．組織観察 用腐食剤はパルメトロン No.2 を用いた，組織観察を終わ った一部の試料は島津製 EMX-SM 型X線マイクロアナラ イザーによって相成分の確認を行なった。

\section{IV. 実験結果と考察}

示差熱分析曲線の代表例を Fig.1 に示す. 例示した示差 曲線の各変化点は組織観察の結果などより次のように考え られた. (a) 図の試料 (番号 28) では $394^{\circ} \mathrm{C}$ で初晶クを, 369 ${ }^{\circ} \mathrm{C}$ で共晶ク+ $\mathrm{Mg}_{2} \mathrm{Zn}_{11}$ を晶出することを示し, (b) 図の試料

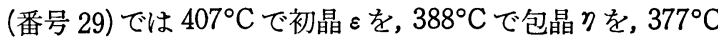
でさらに 2 次晶りを晶出することを示している。また EPMA 分析の例を示すと, Photo.1 は試料 (番号 47) のプ ロフィルで，これよりをとDの相確認を行ならことができ る.

全試料の示差熱分析の結果は Table 2 にまとめて示し た. 最大 5 段階の変化点がそれぞれの組成に従って得られ た.

まず Köster および渡辺の状態図で, 基本的に異なる最 低温度における不変系反応過程の検討を行なった. $\mathrm{Mg}$ 量 を約 $2 \%$ と一定にして, $\mathrm{Cu}$ 量のみを変化させた 5 個の試 料(番号 $26,27,28,29,30$ )についての実験を最初に行なっ た。その結果 Fig.2に示すよらな断面状態図が得られた。

Table 1 Chemical compositions of the alloys used in the present work (wt\%)

\begin{tabular}{|c|c|c|c|c|c|c|c|c|c|c|c|c|c|}
\hline \multirow{2}{*}{$\begin{array}{c}\text { Sample } \\
\text { No. }\end{array}$} & \multicolumn{3}{|c|}{ Nominal compo. } & \multicolumn{3}{|c|}{ Analytical compo. } & \multirow{2}{*}{$\begin{array}{c}\text { Sample } \\
\text { No. }\end{array}$} & \multicolumn{3}{|c|}{ Nominal compo. } & \multicolumn{3}{|c|}{ Analytical compo. } \\
\hline & $\mathrm{Cu}$ & $\mathrm{Mg}$ & $\mathrm{Zn}$ & $\mathrm{Cu}$ & $\mathrm{Mg}$ & $\mathrm{Zn}$ & & $\mathrm{Cu}$ & $\mathrm{Mg}$ & $\mathrm{Zn}$ & $\mathrm{Cu}$ & $\mathrm{Mg}$ & $\mathrm{Zn}$ \\
\hline 1 & 1.7 & 0.5 & 97.8 & 1.7 & 0.2 & 98.1 & 27 & 1.0 & 2.0 & 97.0 & 1.1 & 2.0 & 96.9 \\
\hline 2 & "I & 2.0 & 96.3 & 1.6 & 1.5 & 96.9 & 28 & 1.5 & "I & 96.5 & 1.6 & 2.1 & 96.3 \\
\hline 3 & "I & 3.0 & 95.3 & 1.7 & 2.8 & 95.0 & 29 & 2.0 & "I & 96.0 & 2.1 & 2.3 & 95.6 \\
\hline 4 & "I & 4.0 & 94.3 & 1.9 & 3.9 & 94.2 & 30 & 3.0 & "I & 95.0 & 2.9 & 2.2 & 94.9 \\
\hline 5 & "I & 5.0 & 93.3 & 2.0 & 4.8 & 93.2 & 31 & 1.0 & 5.0 & 94.0 & 0.9 & 4.8 & 94.3 \\
\hline 6 & "I & 6.0 & 92.3 & 1.9 & 5.5 & 92.6 & 32 & 2.0 & "I & 93.0 & 2.3 & 5.2 & 92.5 \\
\hline 7 & "I & 7.0 & 91.3 & 1.9 & 7.1 & 91.0 & 33 & 4.0 & "I & 91.3 & 3.9 & 5.4 & 90.7 \\
\hline 8 & "I & 8.0 & 90.3 & 1.8 & 8.1 & 90.1 & 34 & 7.0 & "I & 88.3 & 6.8 & 5.2 & 87.0 \\
\hline 9 & "I & 10.0 & 88.3 & 1.7 & 9.6 & 88.7 & 35 & 11.0 & "I & 84.0 & 10.7 & 5.3 & 84.0 \\
\hline 10 & "I & 12.0 & 86.3 & 1.9 & 12.4 & 85.7 & 36 & 16.0 & "I & 79.0 & 15.9 & 4.8 & 79.3 \\
\hline 11 & "I & 14.0 & 84.3 & 1.7 & 13.6 & 84.7 & 37 & 19.0 & "I & 76.0 & 19.7 & 4.6 & 75.7 \\
\hline 12 & 6.0 & 0.5 & 93.5 & 6.7 & 0.1 & 93.2 & 38 & 23.0 & "I & 72.0 & 21.9 & 5.2 & 72.9 \\
\hline 13 & "I & 2.0 & 92.0 & 6.8 & 0.8 & 92.4 & 39 & 30.0 & 1.0 & 69.0 & 32.2 & 0.8 & 67.0 \\
\hline 14 & "I & 3.0 & 91.0 & 6.0 & 2.4 & 91.6 & 40 & 2.0 & 7.0 & 91.0 & 2.3 & 7.5 & 90.2 \\
\hline 15 & II & 5.0 & 89.0 & 6.7 & 4.2 & 89.1 & 41 & 2.5 & 2.5 & 95.0 & 2.7 & 2.3 & 95.0 \\
\hline 16 & "I & 7.0 & 87.0 & 6.0 & 6.5 & 87.5 & 42 & 7.0 & 7.0 & 86.0 & 7.0 & 6.8 & 86.2 \\
\hline 17 & "I & 10.0 & 84.0 & 6.0 & 11.4 & 92.6 & 43 & 8.0 & 2.5 & 89.5 & 7.8 & 3.2 & 89.0 \\
\hline 18 & "I & 14.0 & 80.0 & 6.4 & 13.5 & 80.1 & 44 & 9.0 & 9.0 & 82.0 & 9.8 & 7.9 & 82.3 \\
\hline 19 & 15.0 & 0.5 & 84.5 & 15.3 & 0.4 & 84.3 & 45 & 16.0 & 0.5 & 83.5 & 16.2 & 0.1 & 83.7 \\
\hline 20 & II & 1.0 & 84.0 & 15.9 & 0.8 & 83.3 & 46 & 18.0 & 3.0 & 79.0 & 18.9 & 3.1 & 78.0 \\
\hline 21 & "I & 2.0 & 83.0 & 14.7 & 2.2 & 83.1 & 47 & 18.0 & 12.0 & 70.0 & 17.1 & 11.0 & 71.9 \\
\hline 22 & " & 5.0 & 80.0 & 15.5 & 6.1 & 78.4 & 48 & 23.0 & 3.0 & 74.0 & 23.3 & 2.0 & 74.7 \\
\hline 23 & "I & 7.0 & 78.0 & 15.4 & 7.4 & 77.2 & 49 & 0.6 & 15.0 & 84.4 & 0.8 & 12.5 & 86.7 \\
\hline 24 & "I & 9.0 & 76.0 & 15.0 & 9.0 & 76.0 & 50 & 6.0 & 8.0 & 86.0 & 6.5 & 8.1 & 85.4 \\
\hline 25 & "I & 12.0 & 73.0 & 14.8 & 12.6 & 72.6 & 51 & 6.0 & 12.0 & 82.0 & 5.9 & 13.1 & 81.0 \\
\hline 26 & 0.5 & 2.0 & 97.5 & 0.6 & 1.9 & 97.5 & 52 & 15.0 & 8.0 & 77.0 & 14.9 & 8.0 & 78.1 \\
\hline
\end{tabular}




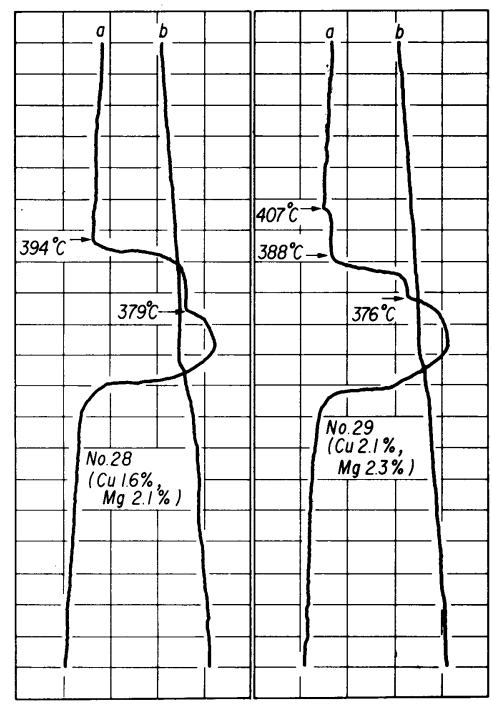

Fig.1 Typical cooling curves in thermal analysis a : Differential, b : Normal (Sample No.28 and 29)

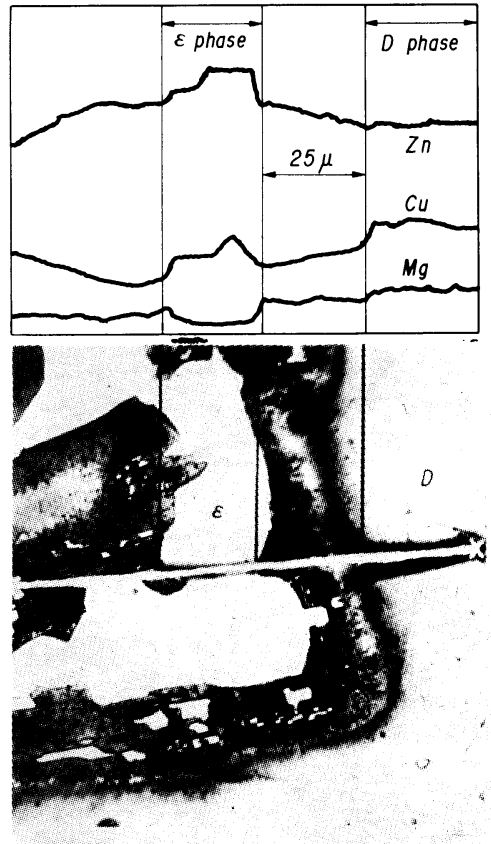

Photo.1 EPMA profiles of sample No.47

Table 2 Rest points in cooling curves $\left({ }^{\circ} \mathrm{C}\right)$

Sample No. 1 st pt. 2 nd pt. 3 rd pt. 4 th pt. 5 th pt. Sample No. 1 st pt. 2 nd pt. 3 rd pt. 4 th pt. 5 th pt.

\begin{tabular}{|c|c|c|c|c|c|c|c|c|c|c|c|}
\hline $\begin{array}{r}1 \\
2 \\
3 \\
4 \\
5 \\
6 \\
7 \\
8 \\
9 \\
10 \\
11 \\
12 \\
13 \\
14 \\
15 \\
16 \\
17 \\
18 \\
19 \\
20 \\
21 \\
22 \\
23 \\
24 \\
25 \\
26\end{array}$ & $\begin{array}{l}419 \\
413 \\
385 \\
381 \\
408 \\
430 \\
503 \\
543 \\
591 \\
612 \\
615 \\
533 \\
521 \\
500 \\
485 \\
550 \\
652 \\
660 \\
658 \\
661 \\
642 \\
605 \\
599 \\
665 \\
705 \\
394\end{array}$ & $\begin{array}{l} \\
\\
410 \\
427 \\
420 \\
382 \\
461 \\
502 \\
539 \\
552 \\
583 \\
587 \\
\\
583 \\
620 \\
640 \\
357\end{array}$ & $\begin{array}{l}468 \\
460 \\
525 \\
557 \\
557 \\
556 \\
557\end{array}$ & $\begin{array}{l}378 \\
370 \\
385 \\
384\end{array}$ & $\begin{array}{l}360 \\
364 \\
367 \\
366 \\
376 \\
378 \\
378 \\
378 \\
380 \\
380 \\
\\
366 \\
367 \\
378 \\
378 \\
377 \\
\end{array}$ & $\begin{array}{l}27 \\
28 \\
29 \\
30 \\
31 \\
32 \\
33 \\
34 \\
35 \\
36 \\
37 \\
38 \\
39 \\
40 \\
41 \\
42 \\
43 \\
44 \\
45 \\
46 \\
47 \\
48 \\
49 \\
50 \\
51 \\
52\end{array}$ & $\begin{array}{l}393 \\
394 \\
407 \\
450 \\
392 \\
420 \\
466 \\
503 \\
572 \\
615 \\
655 \\
668 \\
790 \\
501 \\
448 \\
580 \\
519 \\
624 \\
662 \\
667 \\
708 \\
712 \\
580 \\
620 \\
649 \\
628\end{array}$ & $\begin{array}{l}358 \\
369 \\
388 \\
370 \\
\\
476 \\
525 \\
568 \\
603 \\
601 \\
720 \\
403 \\
\\
442 \\
593 \\
\\
586 \\
565 \\
516 \\
548\end{array}$ & $\begin{array}{l}478 \\
557 \\
557\end{array}$ & $\begin{array}{l}390 \\
387 \\
\\
513 \\
515 \\
515\end{array}$ & $\begin{array}{l}378 \\
367 \\
378 \\
378 \\
379 \\
\\
378 \\
380 \\
378\end{array}$ \\
\hline
\end{tabular}

観察組織の代表例として Photo.2および3を示す. Photo.2 の初晶はクで, そのまわりに共晶ク $+\mathrm{Mg}_{2} \mathrm{Zn}_{11}$ がみられる. Photo. 3 の初晶とは中央部にみられる特異な形をした白色 相であり，その周囲に共晶と+クおよび 2 次晶クがみられ る. その他の試料の組織とくにその初晶を調べることによ って, Fig.3のような本 3 元系 $\mathrm{Zn}$ 隅の拡大状態図が得ら れた.この図によると $\mathrm{Zn}-\mathrm{Cu} 2$ 元系状態㘠の包晶点 $\mathrm{P}_{1}$ は,
細い破線で示される渡辺のものと類似のコースを通って不 変系反応点 $\mathrm{S}_{1}$ に降下している. この反応は $367^{\circ} \mathrm{C}$ におけ る次のような包共晶反応であると考えられた。

$$
\mathrm{L}+\varepsilon \rightleftharpoons \eta+\mathrm{Mg}_{2} \mathrm{Zn}_{11}
$$

この反応が終わると液相は $\mathrm{Zn}-\mathrm{Mg} 2$ 元系状態図の共晶 点 $\mathrm{E}_{2}$ に落ちこんで㠜固を終わる. すなわちこの不変系反 応後の過程はKöster のものと同様である。しかし著者ら 
の状態脑では $\mathrm{Zn}-\mathrm{Mg} 2$ 元系状態図の包晶点 $\mathrm{P}_{4}$ は $\mathrm{Mg}$ 量の 多い側に現われる不変系反応点(後述の $S_{3}$ ) に降下して行 く、それゆえ㘠に実線で示したKöster のものとも異なっ た新しい $\mathrm{Zn}-\mathrm{Cu}-\mathrm{Mg} 3$ 元系状態図の $\mathrm{Zn}$ 隅が得られた。 こ のことは前二者の実験点が少ないために，著者らのような 明確な結果が得られなかったものと思われる.

次に本研究範囲内の平衡関係を明らかにするため, 4 種 類の断面状態図を作成した。 $\mathrm{Cu} 1.7,6.0$ および $15.0 \%$ と一定にした場合のそれらを Fig.4，5 および 6 に示した.

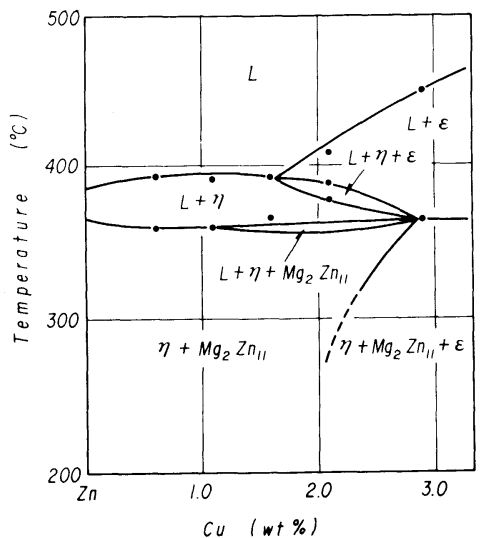

Fig.2 Vertical section at $2 \% \mathrm{Mg}$ in the $\mathrm{Zn}-\mathrm{Cu}-\mathrm{Mg}$ system

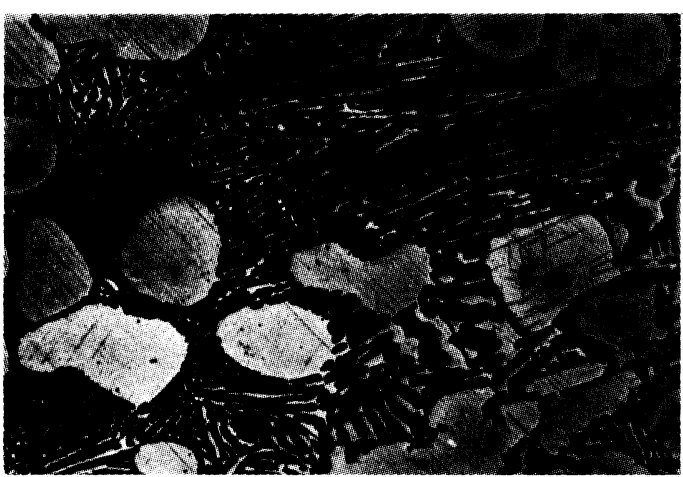

Photo. $2 \mathrm{Zn}-1.6 \% \mathrm{Cu}-2.1 \% \mathrm{Mg}$ primary $\eta$, eutectic $\eta+\mathrm{Mg}_{2} \mathrm{Zn}_{11}(\times 100)$

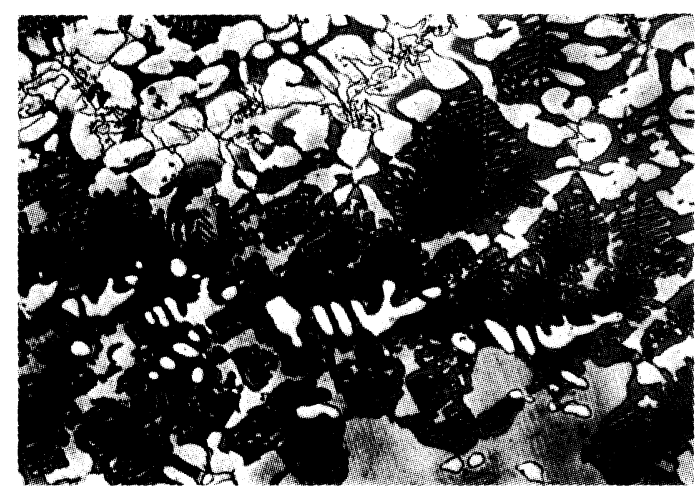

Photo.3 $\mathrm{Zn}-2.1 \% \mathrm{Cu}-2.3 \% \mathrm{Mg}$ primary $\varepsilon$, eutectic $\eta+\varepsilon$, secondary $\eta(\times 100)$
Fig.4 では 3.0 5.0\% Mg で 前記（1）の包共晶反応に関与 し， $4.5 \sim 12.5 \% \mathrm{Mg}$ で $378^{\circ} \mathrm{C}$ に批る次の包共晶反応に

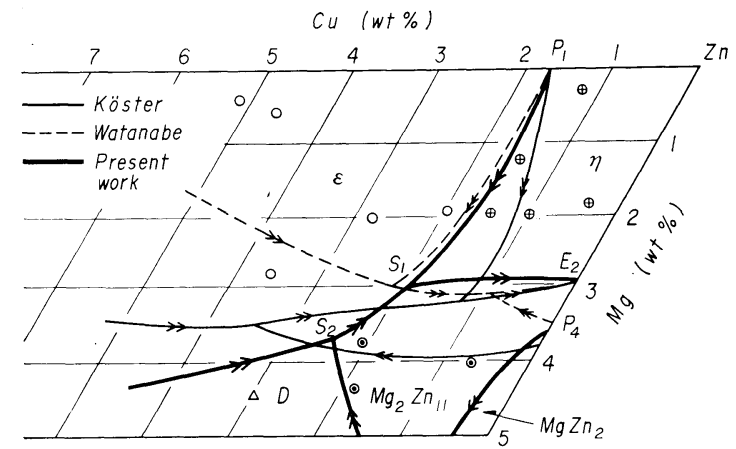

Fig.3 Primary surface of each phase in the equilibrium diagram of the $\mathrm{Zn}$ rich corner of the $\mathrm{Zn}-5 \% \mathrm{Cu}-$ $5 \% \mathrm{Mg}$ system

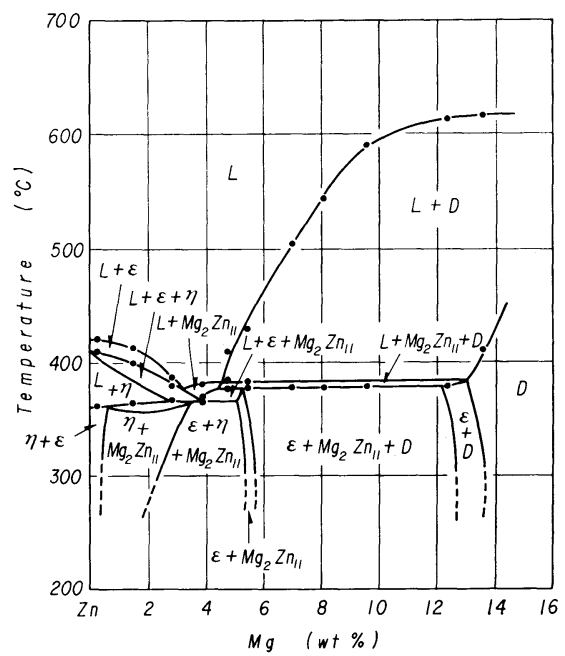

Fig.4 Vertical section at $1.7 \% \mathrm{Cu}$ in the $\mathrm{Zn}-\mathrm{Cu}-\mathrm{Mg}$ system

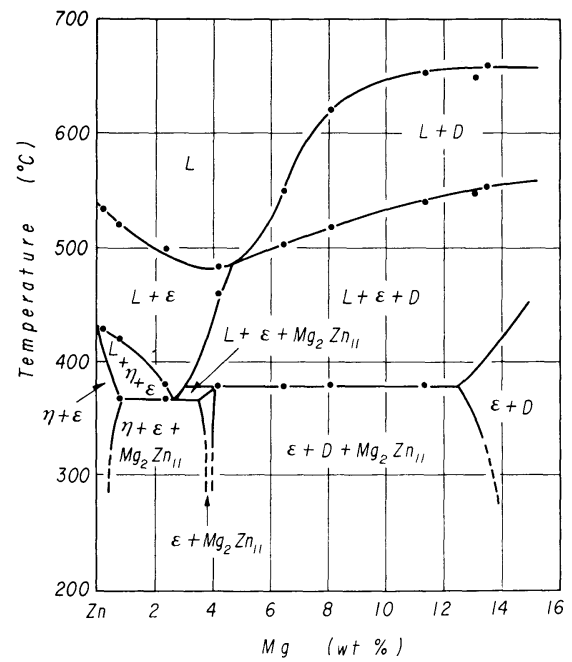

Fig.5 Vertical section at $6 \% \mathrm{Cu}$ in the $\mathrm{Zn}-\mathrm{Cu}-\mathrm{Mg}$ system 


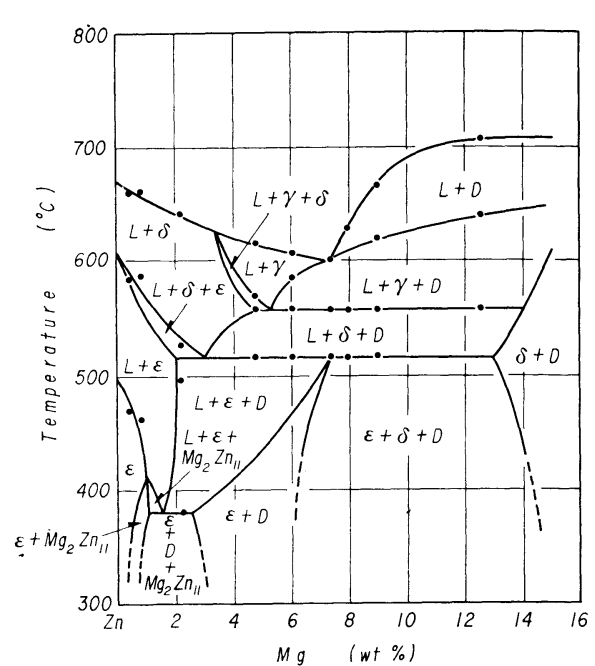

Fig. 6 Vertical section at $15 \% \mathrm{Cu}$ in the $\mathrm{Zn}-\mathrm{Cu}-\mathrm{Mg}$ system

関与することが知られる.

$$
\mathrm{L}+\mathrm{D} \rightleftharpoons \varepsilon+\mathrm{Mg}_{2} \mathrm{Zn}_{11}
$$

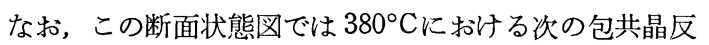
応には関与しない.

$$
\mathrm{L}+\mathrm{MgZn}_{2} \rightleftharpoons \mathrm{Mg}_{2} \mathrm{Zn}_{11}+\mathrm{D}
$$

Fig.5では 1.0〜3.5 および 3.0〜 $12.5 \% \mathrm{Mg}$ で，それぞ れ前記 (1) および ( 2 )の包共晶反応に関与する. Fig.6で は $1.5 \sim 2.5 \% \mathrm{Mg}$ で前記 (2) の包共晶反応に関与する.さ らに 2.0 11.0\% Mg で $515^{\circ} \mathrm{C}$ に抢ける下記 (4)の包共晶 反応に関与し, $4.8 \sim 14.0 \% \mathrm{Mg}$ で $557^{\circ} \mathrm{C}$ における下記 ( 5 ) の包共晶反応にも関与する.

$$
\begin{aligned}
& \mathrm{L}+\delta \rightleftharpoons \varepsilon+\mathrm{D} \\
& \mathrm{L}+\gamma \rightleftharpoons \delta+\mathrm{D}
\end{aligned}
$$

Fig.7 は Mg 5\% 一定の場合の断面状態図であり, 2.0 〜 12.5, 8.5〜19.5 および 14.0〜 $28.0 \% \mathrm{Cu}$ で前記 (2)， (4) 拈よび ( 5 )の包共晶反応に関与する.

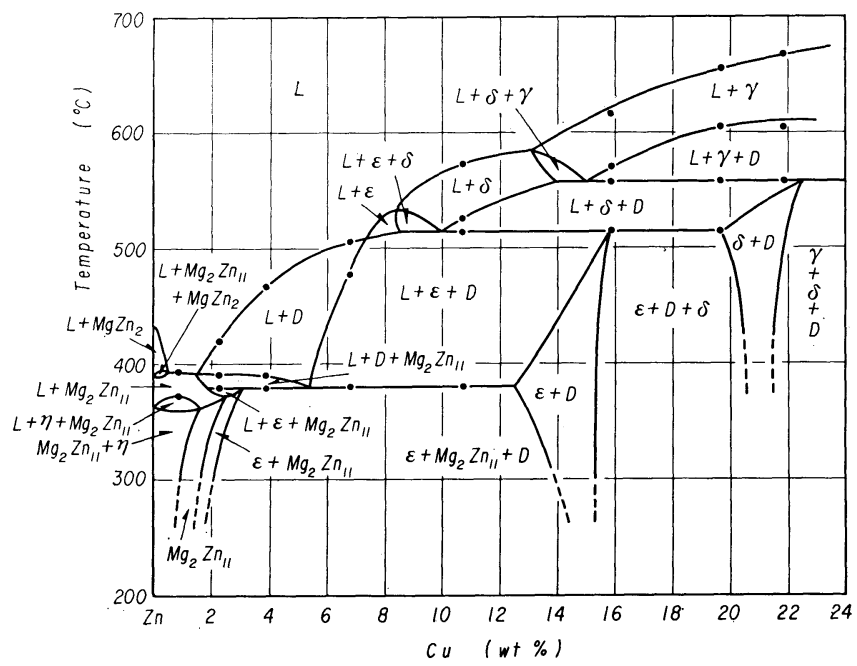

Fig.7 Vertical section at $5 \% \mathrm{Mg}$ in the $\mathrm{Zn}-\mathrm{Cu}-\mathrm{Mg}$ system
次に上述の相の判定のために行なった顕微鏡組織の例を Photo.4 15 に示す. Photo. 4 は初晶クと共晶 $\eta+\mathrm{Mg}_{2} \mathrm{Zn}_{11}$, Photo. 5 は初晶 $\mathrm{Mg}_{2} \mathrm{Zn}_{11}$ と共晶 $\eta+\mathrm{Mg}_{2} \mathrm{Zn}_{11}$ の組織である. Photo. 6 は初晶 D と包晶 $\mathrm{Mg}_{2} \mathrm{Zn}_{11}$ および包共晶 $\mathrm{D}+\mathrm{Mg}_{2} \mathrm{Zn}_{11}$ $+\varepsilon$ の組織である. Photo. 6 中に記入した実線 $\mathrm{AB}$ 内にあ る角ばった黒色物はEPMA 分析の結果ケイ化物であり,今 の場合の研究には関係のないものである. Photo.7 は大き

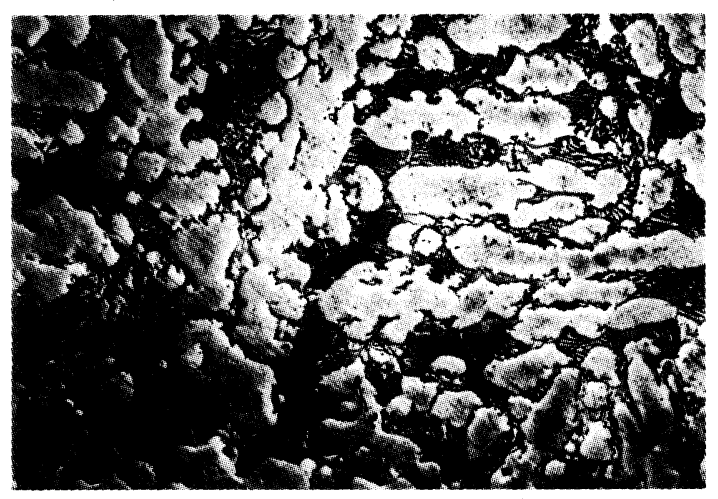

Photo. $4 \mathrm{Zn}-1.6 \% \mathrm{Cu}-1.5 \% \mathrm{Mg}$ primary $\eta$, eutectic $\eta+\mathrm{Mg}_{2} \mathrm{Zn}_{11}(\times 40)$

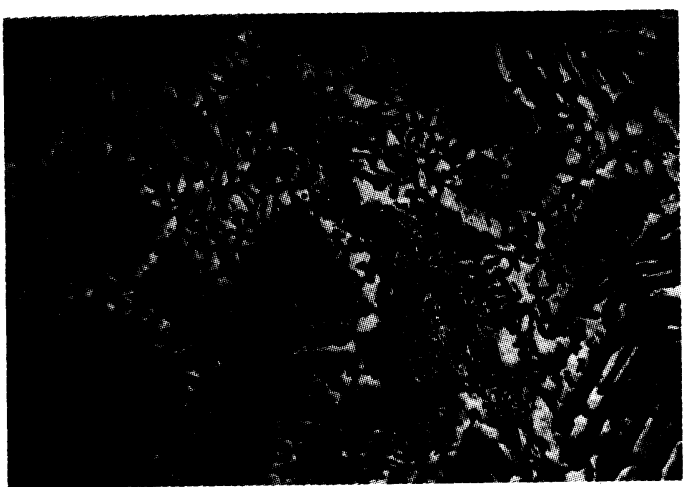

Photo.5 $\mathrm{Zn}-1.9 \% \mathrm{Cu}-3.9 \% \mathrm{Mg}$ primary $\mathrm{Mg}_{2} \mathrm{Zn}_{11}$, eutectic $\mathrm{Mg}_{2} \mathrm{Zn}_{11}+\eta(\times 40)$

な初晶 $\mathrm{D}$ と包晶 $\mathrm{MgZn}_{2}$ および包共晶 $\mathrm{D}+\mathrm{MgZn}_{2}$ $+\mathrm{Mg}_{2} \mathrm{Zn}_{11}$ の組織である. Photo. 8 のやや球形 をした白色相は初晶をであるが，これは実線 $\mathrm{AB}$ の部分の EPMA 分析によって確かめられ た.この初晶の周囲に多量の包晶クがあり，さ らにその間に包共晶 $\varepsilon+\eta+\mathrm{Mg}_{2} \mathrm{Zn}_{11}$ が存在す る. Photo.9 の初晶は $\varepsilon$ であり, 共晶 $\varepsilon+\mathrm{D}$ も存 在するが，Dの結晶化の傾向が大きいため(こ のことは従来の研究(2)(3)によっても認められて (る)，あたかも初晶のような棒状をなしてい る.この組成のものは最後に包共晶 $\varepsilon+D+$ $\mathrm{Mg}_{2} \mathrm{Zn}_{11}$ を晶出するが，棒状晶 $\mathrm{D}$ のわりに包 晶的に変化した $\mathrm{Mg}_{2} \mathrm{Zn}_{11}$ が認められ,このこと も Dの結晶化の傾向が大きいことに関連するも のと考えられた．これらのことは実線 $\mathrm{AB}$ の部 


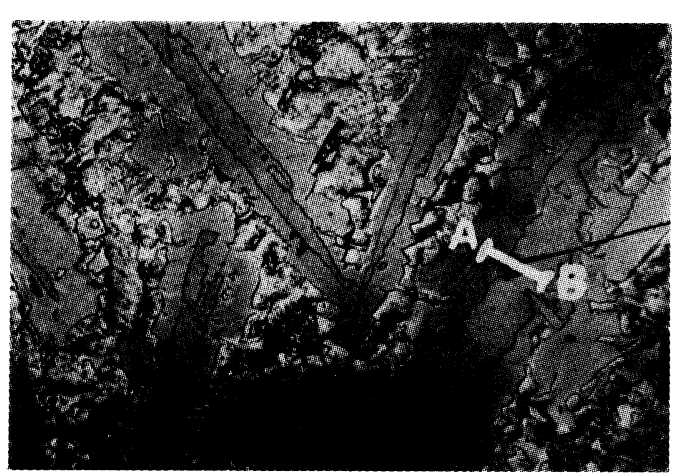

Photo. $6 \mathrm{Zn}-2.0 \% \mathrm{Cu}-4.8 \% \mathrm{Mg}$ primary $\mathrm{D}$, peritectic $\mathrm{Mg}_{2} \mathrm{Zn}_{11}$, peritecto eutectic $\mathrm{D}+\mathrm{Mg}_{2} \mathrm{Zn}_{11}+\varepsilon(\times 40)$

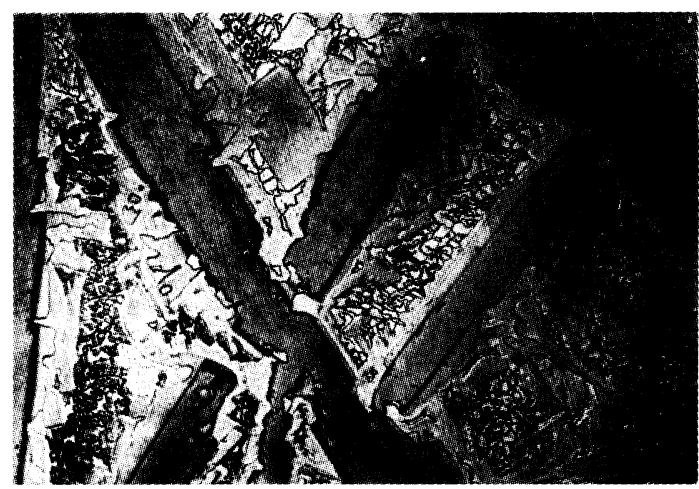

Photo.7 $\mathrm{Zn}-1.8 \% \mathrm{Cu}-8.1 \% \mathrm{Mg}$ primary $\mathrm{D}$, peritectic $M g Z n_{2}$, peritecto eutectic $\mathrm{D}+\mathrm{MgZn}_{2}-\mathrm{Mg}_{2} \mathrm{Zn}_{11}(\times 40)$

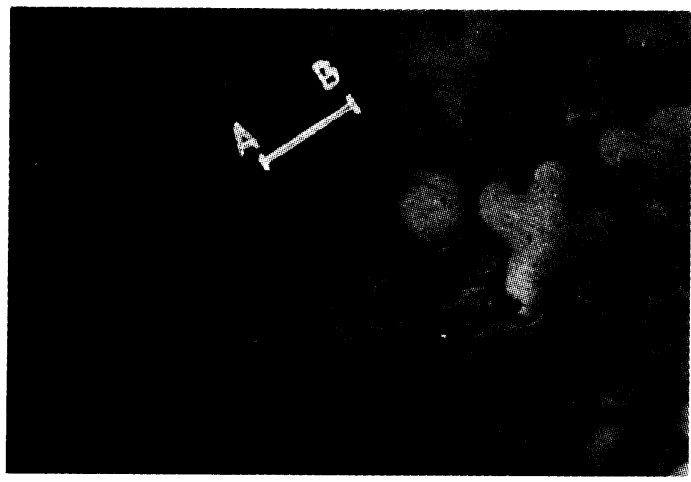

Photo. $8 \mathrm{Zn}-6.8 \% \mathrm{Cu}-0.8 \% \mathrm{Mg}$ primary $\varepsilon$, peritectic $\eta$, peritecto eutectic $\varepsilon+\eta+\mathrm{Mg}_{2} \mathrm{Zn}_{11}(\times 100)$

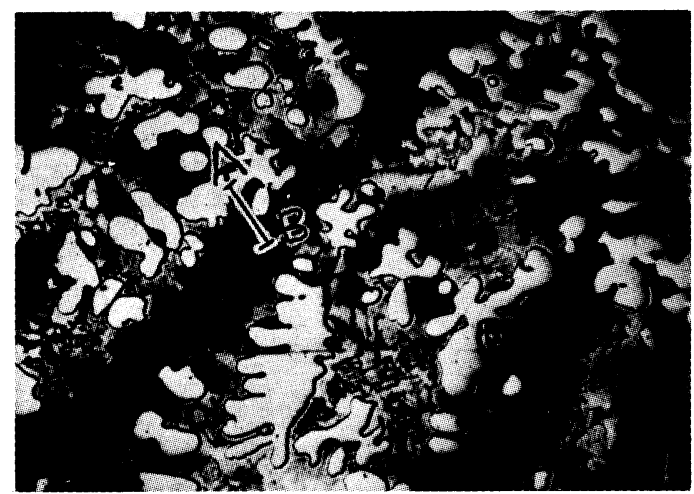

Photo.9 $\mathrm{Zn}-7.8 \% \mathrm{Cu}-3.2 \% \mathrm{Mg}$ primary $\varepsilon$, eutectic $\varepsilon+\mathrm{D}$, peritecto eutectic $\varepsilon+\mathrm{D}+\mathrm{Mg}_{2} \mathrm{Zn}_{11}(\times 40)$

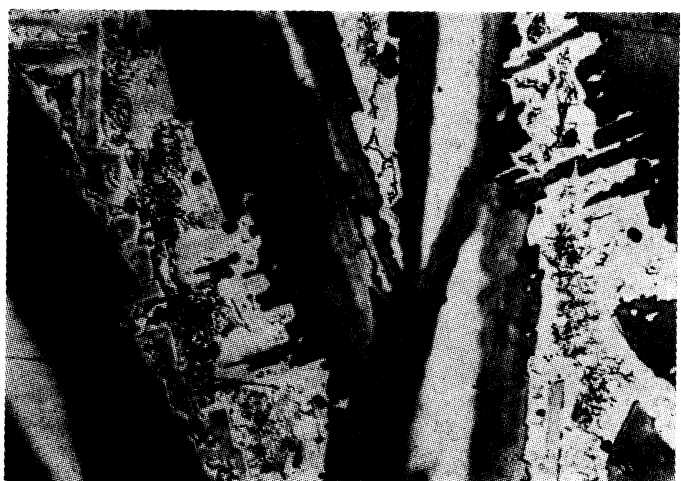

Photo. $10 \mathrm{Zn}-6.0 \% \mathrm{Cu}-11.4 \% \mathrm{Mg}$ primary $\mathrm{D}$, eutectic $\mathrm{D}+\mathrm{MgZn}_{2}(\times 40)$

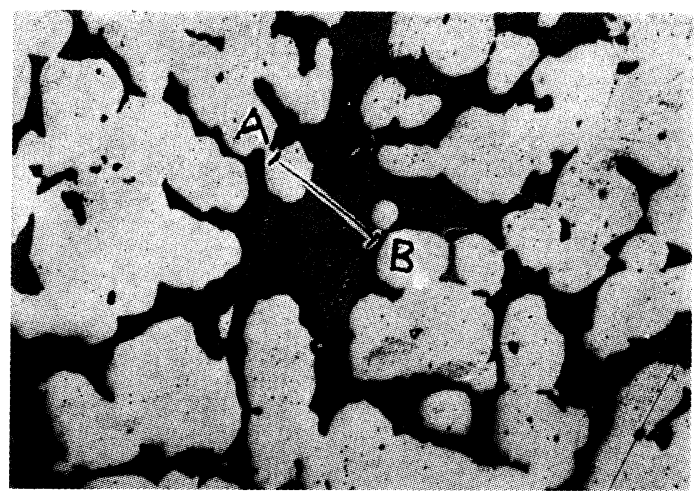

Photo.11 $\mathrm{Zn}-14.7 \% \mathrm{Cu}-2.2 \% \mathrm{Mg}$ primary $\delta$, eutectic $\varepsilon+\delta(\times 100)$

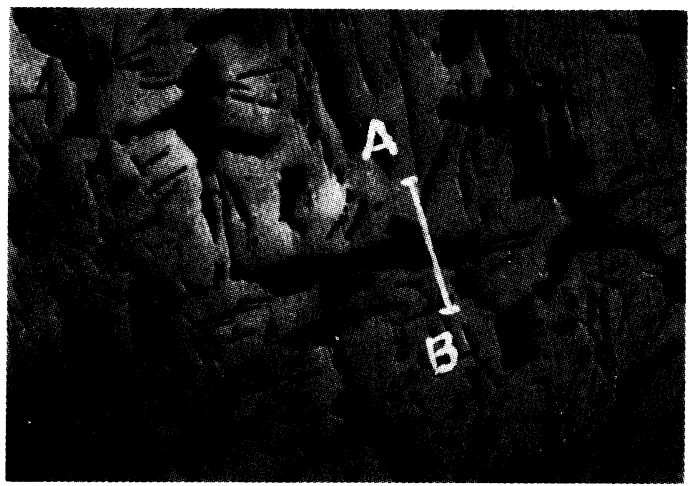

Photo. $12 \mathrm{Zn}-15.5 \% \mathrm{Cu}-6.1 \% \mathrm{Mg}$ primary $r$, eutectic $\gamma+\mathrm{D}(\times 100)$

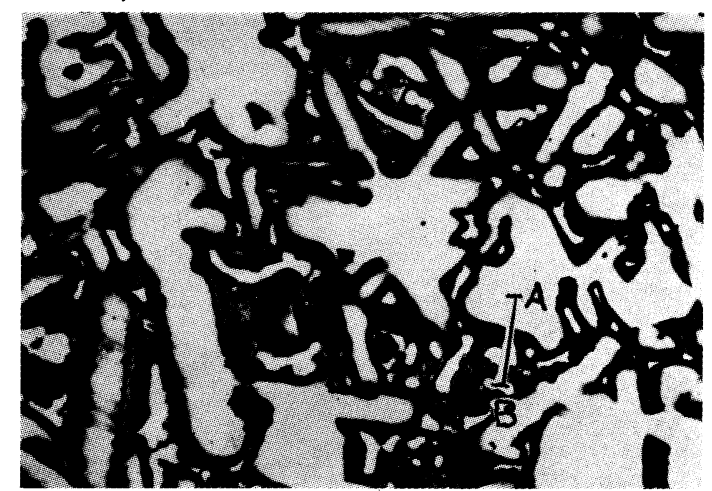

Photo.13 $\mathrm{Zn}-14.8 \% \mathrm{Cu}-12.6 \% \mathrm{Mg}$ primary $\mathrm{D}$, eutectic $D+r(\times 40)$ 


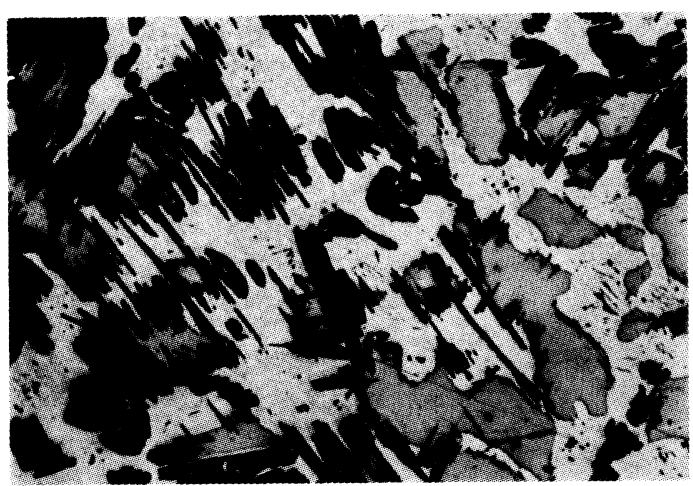

Photo.14 $\mathrm{Zn}-23.3 \% \mathrm{Cu}-2.0 \% \mathrm{Mg}$ primary $r$, eutectic $\gamma+\mathrm{D}$, ternary eutectoid $\gamma+$ $\mathrm{D}+\varepsilon(\times 100)$

分の EPMA 分析で確かめられた. Photo.10は大きく棒状 に晶出した初晶の Dおよび共晶 $\mathrm{D}+\mathrm{MgZn}_{2}$ の組織である. Photo. 11 では初晶 $\delta$ と, その間に黑灰色の $\varepsilon+\delta$ 微細共晶 が存在している.この初晶 $\delta$ は状態図的には 3 元共析分解 $(\delta \rightleftharpoons \varepsilon+\gamma+\mathrm{D})$ によって $\varepsilon+\gamma+\mathrm{D}$ になるべきであるが顕微 鏡組織的には確認されない. Photo. 12 では初晶の $\gamma$ と共晶 の $\gamma+\mathrm{D}$ がみられる. Photo.13の大きな白色相は初晶 D で，その周囲の小さな白色相は共晶 $\mathrm{D}+\gamma$ の Dである。 こ れらのことも実線 $\mathrm{AB}$ の部分の EPMA 分析により確かめ られた. Photo. 14 は多量の初晶 $\gamma$ と黑色針状の共晶 $\gamma+\mathrm{D}$ および包共晶 $\gamma+\mathrm{D}+\delta$ の組織である. $\delta$ は約 $400^{\circ} \mathrm{C}$ で 3 元 共析反応により $\mathrm{D}+\gamma+\varepsilon$ に分解するが，写真では白色相と してみられる. Photo.15 では初晶 $\mathrm{MgZn}_{2}$ がその大部分を 占め, その周囲に包晶 $\mathrm{D}$ と包共晶 $\mathrm{MgZn}_{2}+\mathrm{D}+\mathrm{Mg}_{2} \mathrm{Zn}_{11}$ が みられる。この試料の組成は $\mathrm{Cu}$ 量が比較的少ないので $\mathrm{Zn}-\mathrm{Mg} 2$ 元系の場合と類似の組織となるが, 白色相 Dの存 在が異なる。ささらにその他の合金の組織観察の結果などよ り, 本 3 元系に打忷る $\mathrm{MgZn}_{2}$ 初晶面の存在を確かめるこ とができた.この初晶面は従来の研究では認められていな かったものである.

以上の断面状態図と組織観察の結果より, $\mathrm{Zn}-\mathrm{Cu}-\mathrm{Mg} 3$

$$
\text { Cu }(w+\%)
$$

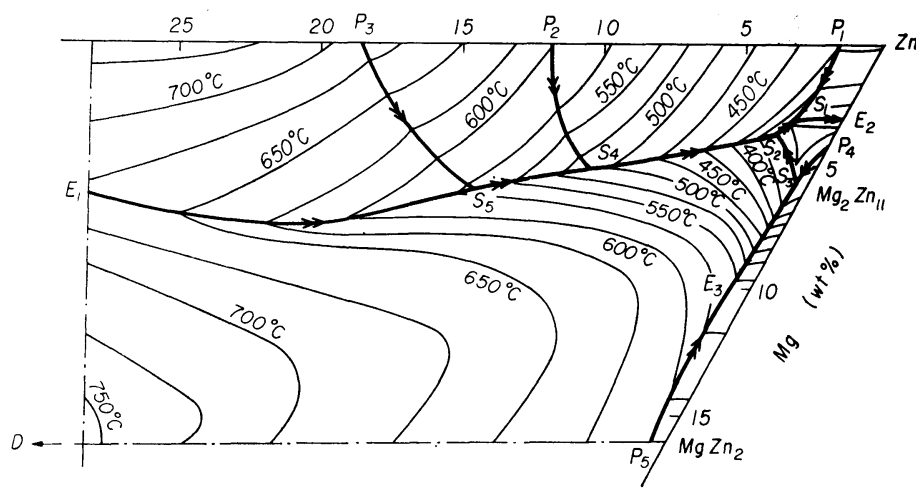

Fig. 8 Liquidus surface of the $\mathrm{Zn}$-rich corner of the $\mathrm{Zn}-\mathrm{Cu}-\mathrm{Mg}$ system

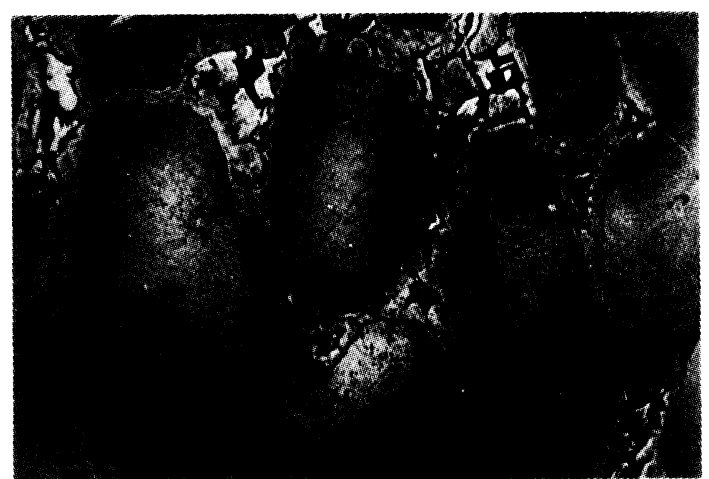

Photo.15 $\mathrm{Zn}-0.5 \% \mathrm{Cu}-12.5 \% \mathrm{Mg}$ primary $\mathrm{MgZn}_{2}$, peritectic $\mathrm{D}$, peritecto eutectic $\mathrm{MgZn}_{2}+$ $\mathrm{D}+\mathrm{Mg}_{2} \mathrm{Zn}_{11}(\times 100)$

元系状態図の $\mathrm{Zn}$ 隅の初晶面は Fig.8に示すようなものと なった. D初晶面が中央部の大部分を占め, これに $\mathrm{Zn}-\mathrm{Cu}$ 2 元系側の $\eta, \varepsilon, \delta$ および $\gamma$ 初晶面が交わり $\mathrm{E}_{1} \mathrm{~S}_{5} \mathrm{~S}_{4} \mathrm{~S}_{2} \mathrm{~S}_{1} \mathrm{E}_{2}$ 共晶線を形成する。 この共晶線に $\mathrm{Zn}-\mathrm{Cu} 2$ 元系状態図の 包晶点 $P_{1}, P_{2}$ および $P_{3}$ より包晶線が降下して, それぞれ $\mathrm{S}_{1}, \mathrm{~S}_{4}$ および $\mathrm{S}_{5}$ の各包共晶点ができる。 また $\mathrm{D}$ 初晶面に $\mathrm{Zn}-\mathrm{Mg} 2$ 元系側の ク, $\mathrm{Mg}_{2} \mathrm{Zn}_{11}$ および $\mathrm{MgZn}_{2}$ 初晶面が交わ り $\mathrm{P}_{5} \mathrm{E}_{3} \mathrm{~S}_{3} \mathrm{~S}_{2}$ 線が形成される。 このらち $\mathrm{P}_{5} \mathrm{E}_{3}$ および $\mathrm{S}_{3} \mathrm{~S}_{2}$ 線 は包晶線で, $\mathrm{E}_{3} \mathrm{~S}_{3}$ 線は共晶線である. $\mathrm{Zn}-\mathrm{Mg} 2$ 元系状態 図の包晶点 $\mathrm{P}_{4}$ より包晶線が降下して $\mathrm{S}_{3}$ の包共晶点ができ る.これより共晶線が出発するも直ちに包晶線に変化し, 前述の $\mathrm{E}_{1} \mathrm{~S}_{5} \mathrm{~S}_{4} \mathrm{~S}_{2} \mathrm{~S}_{1} \mathrm{E}_{2}$ 共晶線と交わって $\mathrm{S}_{2}$ の包共晶点がで きる. $\mathrm{P}_{4} \mathrm{~S}_{3}$ 包晶線と $\mathrm{P}_{5} \mathrm{E}_{3} \mathrm{~S}_{3} \mathrm{~S}_{2}$ 線の存在, すなわち $\mathrm{MgZn}_{2}$ 初晶面の存在が, 従来の研究結果とは異なるもっとも基本 的な点である.

結局本 3 元系状態図の $\mathrm{Zn}$ 隅には次の 5 個の包共晶点の 存在が認められた。すなわち $\mathrm{S}_{1}(2.0 \% \mathrm{Cu}, 3.4 \% \mathrm{Mg}), \mathrm{S}_{2}$ $(2.2 \% \mathrm{Cu}, 3.8 \% \mathrm{Mg}), \mathrm{S}_{3}(0.5 \% \mathrm{Cu}, 5.5 \% \mathrm{Mg}), \mathrm{S}_{4}(8.0 \%$ $\mathrm{Cu}, 5.0 \% \mathrm{Mg})$ および $\mathrm{S}_{5}(12.0 \% \mathrm{Cu}, 6.0 \% \mathrm{Mg})$ の各点で ある. それぞれの点に該当する不変系反忘は，前記 $(1)$,

(2)，(3)，(4)および（5)の式で示された包共晶反応であ る.な拉本研究の組成範囲内には, 約 400 ${ }^{\circ} \mathrm{C}$ にお壮る次の 3 元共析反応にも一部関 与している.

$$
\delta \rightleftharpoons \varepsilon+\gamma+\mathrm{D}
$$

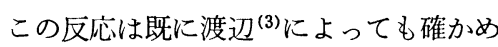
られたものである.

以上を総合して, Fig.9に示すような本 3 元系平衡状態図の $\mathrm{Zn}$ 隅が得られた. 従 来の研究者のものと対比して, 前記 5 個の 包共晶反応を Table 3 に示した. 各相の表 示は著者らのものと一致するようにしてあ る. 各反応温度は研究者によって多少の相 違はあるが大体一致していることがわか 


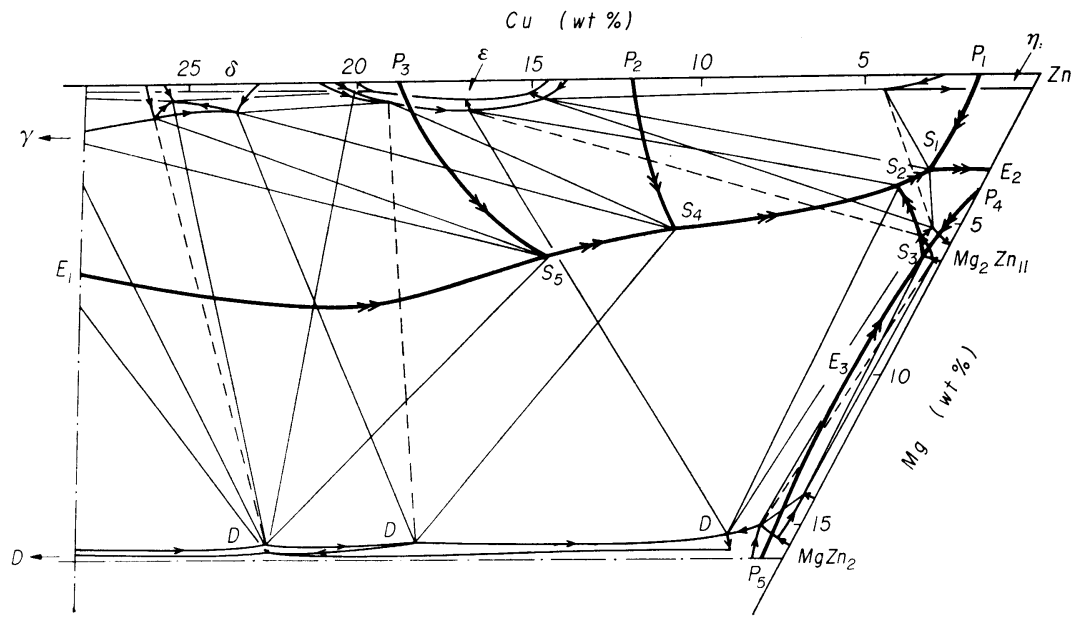

Fig.9 Equilibrium diagram of the $\mathrm{Zn}$-rich corner of the $\mathrm{Zn}-\mathrm{Cu}-\mathrm{Mg}$ system

Table 3 The nonvariant reactions and their temperatures in the present work, together with the previous results on the $\mathrm{Zn}$-rich corner of the $\mathrm{Zn}-\mathrm{Cu}-\mathrm{Mg}$ system

\begin{tabular}{|c|c|c|c|c|c|}
\hline Author & $\mathrm{S}_{1}$ & $\mathrm{~S}_{2}$ & $\mathrm{~S}_{3}$ & $\mathrm{~S}_{4}$ & $\mathrm{~S}_{5}$ \\
\hline W.Köster & $\mathrm{L}+\varepsilon \underset{370^{\circ} \mathrm{C}}{\rightleftharpoons} \mathrm{Mg}_{2} \mathrm{Zn}_{11}$ & $\mathrm{~L}+\mathrm{D} \underset{375^{\circ} \mathrm{C}}{\rightleftharpoons} \varepsilon+\mathrm{Mg}_{2} \mathrm{Zn}_{11}$ & & $\mathrm{~L}+\underset{520^{\circ} \mathrm{C}}{\rightleftharpoons} \varepsilon+\mathrm{D}$ & \\
\hline H. Watanabe & . & $\mathrm{L}+\mathrm{D} \underset{380^{\circ} \mathrm{C}}{\rightleftharpoons} \mathrm{Mg}_{2} \mathrm{Zn}_{11}$ & $\begin{array}{l}\mathrm{L}+\varepsilon \underset{390^{\circ} \mathrm{C}}{\rightleftharpoons}+\mathrm{D} \\
\end{array}$ & $\begin{array}{l}\mathrm{L}+\delta \underset{525^{\circ} \mathrm{C}}{\rightleftharpoons} \varepsilon+\mathrm{D} \\
\quad\end{array}$ & $\mathrm{L}+\underset{540^{\circ} \mathrm{C}}{\rightleftharpoons} \delta+\mathrm{D}$ \\
\hline Present work & $\begin{array}{c}\mathrm{L}+\varepsilon \rightleftharpoons \eta+\mathrm{Mg}_{2} \mathrm{Zn}_{11} \\
367^{\circ} \mathrm{C}\end{array}$ & $\begin{array}{c}\mathrm{L}+\mathrm{D} \rightleftharpoons \varepsilon+\mathrm{Mg}_{2} \mathrm{Zn}_{11} \\
378^{\circ} \mathrm{C}\end{array}$ & $\begin{array}{c}\mathrm{L}+\mathrm{MgZn}_{2} \rightleftharpoons \\
\mathrm{Mg}_{2} \underset{\mathrm{Zn}_{11}}{\rightleftharpoons}+\mathrm{D} \\
380^{\circ} \mathrm{C}\end{array}$ & $\begin{array}{c}\mathrm{L}+\delta \rightleftharpoons \varepsilon+\mathrm{D} \\
515^{\circ} \mathrm{C}\end{array}$ & $\begin{array}{c}\mathrm{L}+\gamma \rightleftharpoons \delta+\mathrm{D} \\
557^{\circ} \mathrm{C}\end{array}$ \\
\hline
\end{tabular}

る.しかし，それぞれの反応過程は異なっており，Köster は $\delta$ を無視するとともに， Dと $\mathrm{MgZn}_{2}$ との区別をしなか った，渡辺は $\delta$ を考慮したが，やはり $\mathrm{D} と \mathrm{MgZn}_{2}$ との区 別をしていない, 結局, 包共晶反応の数としては, Köster が 3 個, 渡辺が 4 個であるに対して著者らは 5 個認めたわ けである. 著者らの状態図における諸反応を Table 4 にま とめて表示した。

Table 4 The reactions on the $\mathrm{Zn}$-rich corner of the $\mathrm{Zn}-\mathrm{Cu}-\mathrm{Mg}$ system

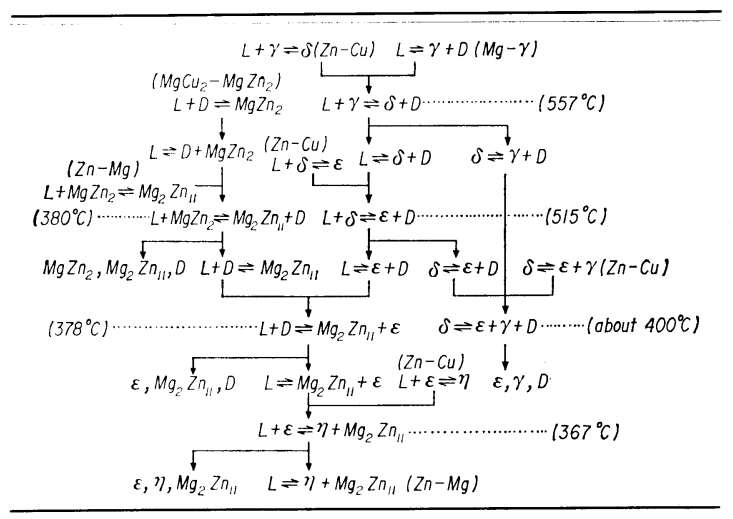

V. 総 括

(1) $\mathrm{Zn}-\mathrm{Cu}-\mathrm{Mg} 3$ 元系平衡状態図の $\mathrm{Zn}$ 隅, すなわち $\mathrm{Cu}$

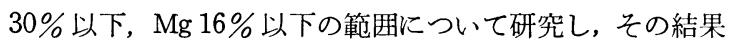
Fig.9の新しい状態図を得た.

(2) 従来の研究で全く異なっていた $\mathrm{Cu} 5 \%$ 以下, $\mathrm{Mg}$ $5 \%$ 以下の部分を最初に検討し, その結果 Fig. 3 の新しい 状態図を決定することがでさた。

(3) 本 3 元系平衡状態図には $\mathrm{MgZn}_{2}$ の初晶面の存在す ることを確かめ, それにともなって新しい包共晶反応の存 在を明らかにした。

（4）本 3 元系平衡状態図の範囲内には次の 5 個の包共晶 反応と 1 個の 3 元共析反応の存在することを認めた.
(a) $\mathrm{L}+\varepsilon \rightleftharpoons \eta+\mathrm{Mg}_{2} \mathrm{Zn}_{11} \quad 367^{\circ} \mathrm{C}$
(b) $\mathrm{L}+\mathrm{D} \rightleftharpoons \varepsilon+\mathrm{Mg}_{2} \mathrm{Zn}_{11} \quad 378^{\circ} \mathrm{C}$
(c) $\mathrm{L}+\mathrm{MgZn}_{2} \rightleftharpoons \mathrm{Mg}_{2} \mathrm{Zn}_{11}+\mathrm{D} 380^{\circ} \mathrm{C}$
(d) $\mathrm{L}+\delta \rightleftharpoons \varepsilon+\mathrm{D} \quad 515^{\circ} \mathrm{C}$
(e) $\mathrm{L}+\gamma \rightleftharpoons \delta+\mathrm{D} \quad 557^{\circ} \mathrm{C}$
(f) $\delta \rightleftharpoons \varepsilon+r+\mathrm{D} \quad$ 約 $400^{\circ} \mathrm{C}$ 